\title{
FEATURES
}

\section{France plans new science museum}

France is soon to publish a report proposing the construction of the largest science museum in the world. Compiled on the instructions of the President Giscard d'Estaing by Professor Maurice Levy and a committee of 11 , the report was completed last October after a 12-month study. However, Giscard d'Estaing has still not publicly released it; clearly there is a lively debate going on within the government about just how large a commitment France can afford to make to such a project at a time of economic squeeze. But there is no doubt that the project will go ahead in some form; even if money is hard to find, the advantages are too large to ignore.

First, there is the location. A disused abattoir called La Villette squats in the north-east corner of Paris. Its grounds cover $\mathbf{5 2}$ hectares, making it the largest open space in Paris outside the Bois de Boulogne. Abandoned almost ten years ago, the prey of property speculation and grandiose schemes, La Villette has long been the biggest property scandal in Paris. Thus its planned transformation into a park and a new Museum of Sciences and Industry (with a concert auditorium to be added later) will remove a painful reminder of a rather disreputable past. The conversion could be ready in five years at an estimated cost of 363 million FF.

Second, there is the equally scandalous condition of Paris's present science museum, the Palace of Discovery. Housed in a crumbling building constructed in the 19th century as a "temporary" exhibition hall, much of the equipment dates from the 1930s when Jean Perrin created it. Conceived of as one of a series of museums, it had to crowd in examples of all the sciences when the plans for the others were abandoned. Perrin's idea of "familiarising our visitors with the fundamental research by which science is created, through daily re-creations of the great experiments" has, through lack of funds and support, largely degenerated into formal lecture-demonstrations by underpaid staff to audiences increasingly made up of reluctant schoolchildren and middle-aged professionals. Meanwhile, the Conservatory of Arts and Crafts, set up at the time of the Revolution to be a collection of all the "originals of instruments or machines invented or perfected" in France, has remained a hodgepodge of machines, with almost no representation of very old, or very recent technologies, or those not originating in France.

So the decision to build a new museum of science, in La Villette, has a compelling logic.

Professor Lévy sees the museum as a counterweight to the way science is taught and popularised in France. As in most

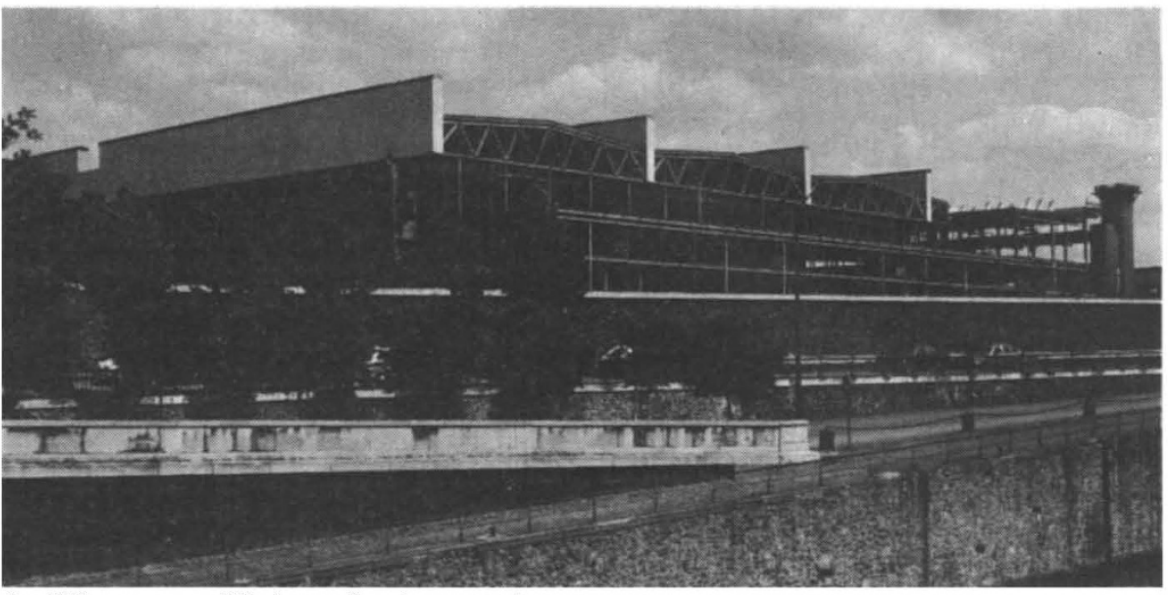

La Villette: a possible home for the new science museum.

countries, the public view science as a formalised, completed structure, rigidly demarcated as the domain of "experts", pursuing their unfathomable goals by unknowable means. In France this is particularly marked, and leads to a virtual absence of public debate on scientific and technological questions. The new museum, Lévy feels, must be the initiator of such debates. "Science", he points out, "is too important to be left to the scientists."

Hitherto, most museums have followed one of three patterns. One such is typified by the Palace of Discovery: the hierarchial initiation of the layperson into the mysteries of science by the "expert", the quasi-academic lecture and demonstration. The conservatory of Arts and Crafts is an example of the second type: a dusty collection of artefacts, the frozen detritus of past accomplishments. Finally, there is the third kind, found in most postwar museums, where there is a tendency to represent science as a series of disjointed tricks, black boxes which, when their buttons are pushed by the visitor, dutifuly trot out their magical effects.

But now modern technology and the increasingly sophisticated demands of the public, Lévy claims, has made possible "not an amelioration but a mutation" in the concept of a museum. New methods of communication will allow people to participate in scientific and technological decisions by giving them real access to the basic conceptual foundations of science and their practical consequences through active participation and debate.

This will happen in two ways. First, the flexibility of modern techniques permits "branching", the creation of an autonomous set of subthemes so that each museum visitor will be able to follow his or her own interests and needs in a certain subject, from basic concept to detailed application. Second, the museum at $\mathrm{La}$ Villette will make use of the "science in the streets" movement where scientists at conferences also present their ideas in local public forums, answering questions and stimulating debate. La Villette plans to take this up in the form of a series of weekend events held every two or three months in which scientists and technologists would engage the public at open meetings at the museum as equal partners in a discussion of the consequences of what they have done.

There are a number of questions however which have been raised about the project. Bertrand Gille, an eminent French historian of technology, has pointed out that the relations of science to technology is far from unproblematic. A lack of historical perspective, the propagation of the idea that there is "one" technology flowing effortlessly from scientific advance are "received ideas" which still inform much thinking about the new museum, and tend to undermine the possibility of the critical approach that the museum is supposed encourage. Furthermore, Michel Biezunski, one of the originators of the interactive computer systems forming the base of the museum, is concerned about the control of the content of the displays. The public depends on the information in the exhibitions, and since both science and industry have a vested interest in stressing the positive side, where is the space for informed, critical debate?

Answering these criticisms, Lévy insists that the museum will try to show science as a "human endeavour", possibly by the inclusion of examples of scientific failures as well as successes. Further, he also insists that the museum staff, not government or industry, control the content of all exhibitions. But doubts persist. It is, after all, in the very nature of a museum to present historical successes, for they have become "knowledge". It may be felt that few people would come to see displays of technical failure, even though such exhibits might really illuminate how science works.

Jim Ritter 